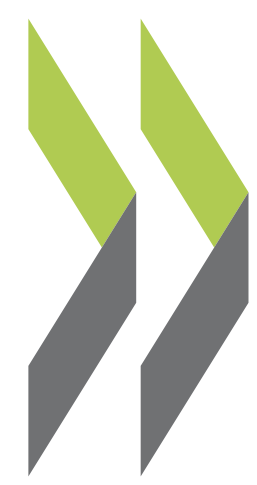

OECD Economics Department Working Papers No. 474

Reforming Federal Fiscal Relations in Austria

Andrés Fuentes, Eckhard Wurzel,

\section{Andreas Wörgötter}

https://dx.doi.org/10.1787/880241418571 
Organisation de Coopération et de Développement Economiques

Organisation for Economic Co-operation and Development

23-Jan-2006

ECONOMICS DEPARTMENT

English, French

REFORMING FEDERAL FISCAL RELATIONS IN AUSTRIA

ECONOMICS DEPARTMENT WORKING PAPERS NO. 474

By

Andrés Fuentes, Eckhard Wurzel and Andreas Wörgötter

All Economics Department Working Papers are available through OECD's Internet Web site at www.oecd.org/eco/Working_Papers/ 


\section{TABLE OF CONTENTS}

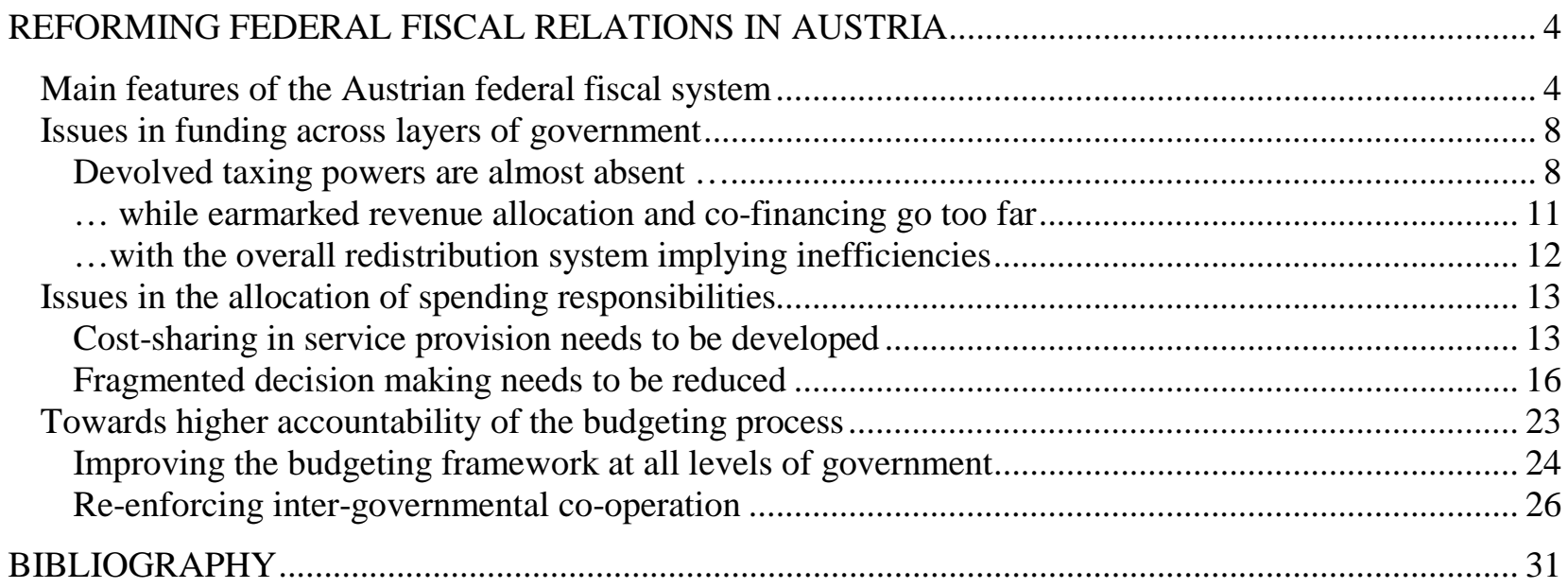

\section{Boxes}

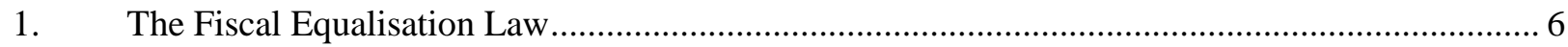

2. Hospital financing: the new agencies for health .................................................................. 19

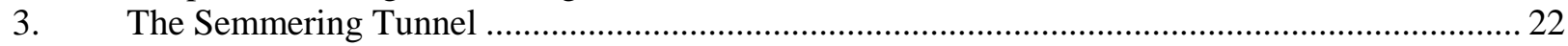

4. An example for improving cost awareness The Austrian Waste Management Tool ................... 23

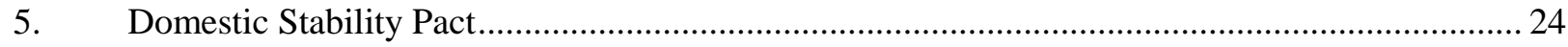

\section{Tables}

1. Spending by subnational governments by main categories ...................................................... 6

\section{Figures}

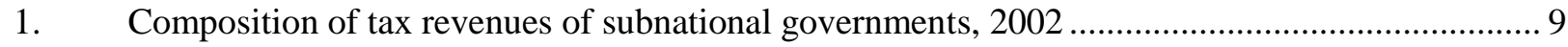

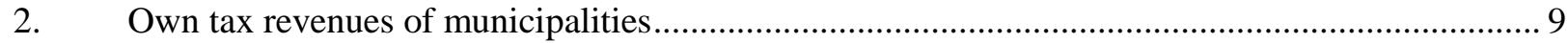

3. Distribution of municipalities by resident population.......................................................... 14

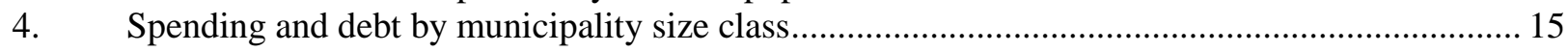

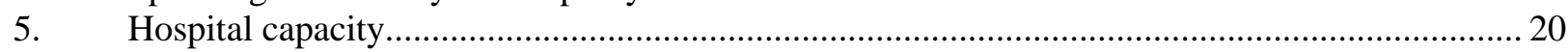




\section{ABSTRACT/RÉSUMÉ \\ Reforming federal fiscal relations in Austria}

This paper reviews the fiscal relations between the three levels of government in Austria and points to the scope for reforming them with a view to improving the efficiency of the public sector. Key areas of public sector activity are subject to complex relations across the three layers of government. Fragmentation of decision-making in some spending programmes, such as hospital care and social assistance benefits, needs to be overcome, concentrating financing and spending responsibilities on one government level. Strengthening co-operation between municipalities as well as amalgamations of small municipalities would allow advantage to be taken of scale economies in the provision of local government services. Stronger tax-raising powers of the municipalities and the states, reform of tax sharing rules and improved budgeting procedures would raise the ability of sub-national governments to match the supply of services to local demand patters and improve accountability to voters.

This Working Paper relates to the 2005 OECD Economic Survey of Austria (www.oecd.org/eco/surveys/austria)

JEL classification: $\mathrm{H} 71, \mathrm{H} 72, \mathrm{H} 77$

Keywords: intergovernmental relations; state and local government finances; federalism

\section{Réformer les relations budgétaires entre la fédération et les autres niveaux d'administration en Autriche}

Ce document rend compte des relations budgétaires entre la fédération et les autres niveaux d'administration en Autriche et met en évidence les possibilités de les faire évoluer en vue d'améliorer l'efficience du secteur public. Les principaux domaines d'activité du secteur public font intervenir des relations budgétaires complexes entre les différents niveaux d'administration. Il faut remédier au morcellement de la prise de décision pour certains programmes de dépenses, notamment les services hospitaliers et l'aide sociale, en regroupant les compétences en matière de financement et de dépense à un seul niveau d'administration. En renforçant la coopération entre les communes et en favorisant leur fusion lorsqu'elles sont de petite taille, on pourrait tirer parti des économies d'échelle pour la fourniture des services publics locaux. En dotant les communes et les Länder de plus larges compétences fiscales, en réformant les règles de partage de l'impôt et en revoyant les procédures budgétaires, on ferait en sorte que les administrations infranationales puissent mieux adapter l'offre de services à la demande locale et aient davantage de comptes à rendre à leur électorat.

Ce document de travail se rapporte à l'Étude économique de l'OCDE de l'Autriche 2005 (www.oecd.org/eco/etudes/autriche)

JEL codes : $\mathrm{H} 71, \mathrm{H} 72, \mathrm{H} 77$.

Mots clés : relations intergouvernementales; finances publiques des états et des municipalités; fédéralisme

Copyright OECD, 2006

Application for permission to reproduce or translate all, or part of, this material should be made to: Head of Publications Service, OECD, 2 rue André-Pascal, 75775 PARIS CEDEX 16, France. 


\title{
REFORMING FEDERAL FISCAL RELATIONS IN AUSTRIA
}

\author{
by \\ Andrés Fuentes, Eckhard Wurzel and Andreas Wörgötter ${ }^{1}$
}

1. Austria is a federal state with three layers of government, with elected government institutions, independent decision making powers and budgetary autonomy - the federation (der Bund), the states (die Länder) and the municipalities (die Gemeinden). The states have substantial legislative powers and the constitution guarantees the autonomy of the municipalities in all local matters. While decentralised decision powers can in principle allow policy makers to take local preferences better into account, federal fiscal relations in Austria generate inefficiencies in resource allocation in some important fields. Hence, reforming federal fiscal relations should have high priority on the policy agenda, linking public sector reform with fiscal consolidation. Indeed, a constitutional convention was installed in Austria in 2004, involving representatives of the various governments, the political parties and the social partners, whose task was to make proposals for constitutional reform that would simplify federal fiscal relations. This paper aims at a more comprehensive account of a number of relevant policy issues.

2. The allocation of revenue-raising and spending competencies across government levels, channels of fiscal equalisation between sub-national governments, and modes of co-financing of spending projects across different layers of government all form part of a complex federal fiscal system, with many interactions between them. The first part of this paper reviews basic characteristics of the Austrian federal fiscal system. The subsequent parts of this paper highlight important aspects of Austrian federal fiscal relations where institutional reforms are likely to generate substantial gains in public sector efficiency. The second section considers policy issues in funding across layers of government. Section three examines issues in the allocation of spending responsibilities, including federal aspects of the provision of social assistance and health care financing. Finally, the last section makes proposals aimed at increasing the accountability of the budgeting process.

\section{Main features of the Austrian federal fiscal system}

3. The constitution lists areas in which only the federal parliament legislates. Areas not included in the list are considered to be the responsibility of the states' parliaments. Major examples of federal legislative responsibilities include higher education and vocational training, some areas of social policy, such as family support and private sector pensions, and labour legislation. State legislative responsibilities include social welfare, health care in the hospital sector, some areas of primary and secondary education (such as regulation of working conditions of teachers), nature conservation, building regulations, and regional infrastructure planning, including transport. Local authorities perform policing and inspection tasks, local planning, infrastructure provision - such as water services - as well as social services.

4. However, in many areas, decision making competences in closely related areas are assigned across different levels of government. For example, the constitution assigns legislative powers on the framework conditions (Grundsatzgesetzgebungskompetenz) of hospital care to the federal level, while it is the states' responsibility to legislate within this framework (Ausfïhrungsgesetzgebung). While teachers' working conditions are legislated by the states, setting up curricula for schools as well as further education are responsibilities of the federal government. Responsibilities also overlap. For example, both state and 
local governments are responsible for the maintenance of schools. Also, most administrative tasks emanating from federal legislation are delegated to the states, and - to a lesser extent - to the municipalities. The latter also fulfil administrative functions delegated by the states. ${ }^{2}$ Some administrative responsibilities, such as in taxation, security and military matters, remain with the federal government, however. ${ }^{3}$

5. The states employ the largest share of government employees of all three levels of government, about $43 \%$, with the federal government and the municipalities employing $38 \%$ and $19 \%$ respectively. ${ }^{4}$ About $30 \%$ of total government spending is spent by sub-national governments (Table 1). Austria occupies a middle position with respect to the decentralisation of government spending within the OECD, although the share of spending of the intermediate level of government is, on aggregate, somewhat lower than in other federally organised member countries. The states' share of general government spending (excluding intra-governmental transfers) increased between 1985 and 2002 while the municipalities' share declined. Rising outlays by the states for social assistance and hospitals - which were accompanied by higher transfers from the municipalities to the states - contributed to this development. Health and social security and welfare spending make up a larger proportion of sub-national government spending in Austria than in most other federal OECD countries (see Table 1). Close to one half of states' total spending and more than one third of municipalities' total spending is accounted for by health care and social spending. Spending and financing responsibilities in both policy areas are fragmented, involving all three levels of government, leaving room for substantial efficiency gains, as outlined further below in the paper.

6. According to the federal constitution, governments of each level need to be given sufficient financial resources to fulfil the tasks assigned to them. Moreover, the constitution prescribes, in principle, that financing responsibilities of different layers of government should match spending powers (Konnexität). However, there is an elaborate system of tax sharing, transfers, and co-financing across the different layers of government. To a large extent these arrangements reflect the objective to achieve roughly equal living conditions in all of Austria, as well as the high value given to co-operation and consensus-driven decision making across government levels. ${ }^{5}$ The federal government and the states have struck agreements on many issues in which both layers of government have certain decision-making powers and coordination is considered beneficial. In some cases, these agreements also involve cofinancing arrangements. For example, the rules governing financing of hospitals are set in temporary agreements between the federal government and the states, and both levels of government (as well as the municipalities) contribute to hospital funding. Further areas subject to co-financing and based on intergovernmental agreements include aspects of environmental regulation, hiring and financing of teachers, as well as rules concerning the use of subsidies for residential construction. A cornerstone regulating the assignment of revenue and spending powers is given by the Fiscal Equalisation Law (Finanzausgleichsgesetz), (see Box 1).

7. Extra-budgetary units have gained importance at all levels of government over the last ten years or so. This further increased the complexity of federal fiscal relations across entities of the public sector, boosting the entanglement of transfers between government and non-governmental public sector entities. Investment of extra-budgetary units - including public sector enterprises - as a percentage of investment by the federal government, the states, municipalities and the social security system increased from $1.7 \%$ in 1995 to $97.6 \%$ in $2003 .{ }^{6}$ 
Table 1 . Spending by sub-national governments by main categories In \% of total sub-national governments' expenditure 2003 or latest year available

\begin{tabular}{|c|c|c|c|c|c|c|c|c|}
\hline \multirow{3}{*}{ Federal countries } & \multicolumn{2}{|c|}{ Public order and safety } & \multicolumn{2}{|c|}{ Education } & \multicolumn{2}{|c|}{ Health } & \multicolumn{2}{|c|}{ Social security \& welfare } \\
\hline & $\begin{array}{c}\text { State, } \\
\text { Region or } \\
\text { Province }\end{array}$ & Local & $\begin{array}{l}\text { State, } \\
\text { Region or } \\
\text { Province }\end{array}$ & Local & $\begin{array}{c}\text { State, } \\
\text { Region or } \\
\text { Province }\end{array}$ & Local & $\begin{array}{c}\text { State, } \\
\text { Region or } \\
\text { Province }\end{array}$ & Local \\
\hline & & & & & & & & \\
\hline Australia (2002) & 9.2 & 2.0 & 25.7 & 0.3 & 22.9 & 1.5 & 6.0 & 5.3 \\
\hline Austria & 0.6 & 2.3 & 20.1 & 17.2 & 19.7 & 17.1 & 20.4 & 18.2 \\
\hline Belgium & 0.2 & 11.9 & 41.3 & 19.9 & 0.7 & 2.0 & 16.5 & 16.1 \\
\hline Canada (2002) & 3.7 & 9.7 & 22.6 & 41.8 & 32.7 & 1.4 & 16.7 & 6.5 \\
\hline Germany & 8.8 & 4.6 & 23.4 & 16.3 & 1.2 & 1.8 & 23.1 & 31.0 \\
\hline Switzerland (2001) & 7.9 & 4.6 & 24.5 & 23.2 & 17.3 & 18.6 & 17.4 & 14.0 \\
\hline United States (2001) & 4.4 & 10.4 & 30.9 & 44.8 & 22.0 & 8.4 & 17.9 & 7.3 \\
\hline \multirow[t]{3}{*}{ Non-weighted average } & 5.0 & 6.5 & 26.9 & 23.3 & 16.6 & 7.3 & 16.9 & 14.1 \\
\hline & \multicolumn{2}{|c|}{$\begin{array}{c}\text { General public } \\
\text { services }\end{array}$} & \multicolumn{2}{|c|}{$\begin{array}{c}\text { Housing \& } \\
\text { community amenities }\end{array}$} & \multicolumn{2}{|c|}{ Economic services } & \multicolumn{2}{|c|}{ Other } \\
\hline & $\begin{array}{c}\text { State, } \\
\text { Region or } \\
\text { Province } \\
\end{array}$ & Local & $\begin{array}{c}\text { State, } \\
\text { Region or } \\
\text { Province }\end{array}$ & Local & $\begin{array}{c}\text { State, } \\
\text { Region or } \\
\text { Province } \\
\end{array}$ & Local & $\begin{array}{c}\text { State, } \\
\text { Region or } \\
\text { Province } \\
\end{array}$ & Local \\
\hline Federal countries & & & & & & & & \\
\hline Australia (2002) & 10.5 & 22.3 & 5.2 & 12.6 & 17.2 & 29.9 & 3.3 & 26.1 \\
\hline Austria & 11.0 & 17.2 & 4.1 & 3.4 & 20.9 & 14.6 & 3.1 & 10.1 \\
\hline Belgium & 17.0 & 23.5 & 1.7 & 1.8 & 15.8 & 11.2 & 6.8 & 13.6 \\
\hline Canada (2002) & 12.4 & 9.6 & 1.3 & 5.9 & 9.6 & 18.5 & 0.9 & 6.7 \\
\hline Germany & 25.8 & 14.7 & 3.7 & 6.8 & 11.6 & 11.9 & 2.5 & 13.1 \\
\hline Switzerland (2001) & 11.6 & 15.9 & 2.1 & 8.0 & 16.8 & 9.8 & 2.4 & 5.9 \\
\hline United States (2001) & 13.2 & 16.2 & 0.7 & 2.1 & 10.3 & 7.4 & 0.4 & 3.4 \\
\hline Non-weighted average & 14.5 & 17.1 & 2.7 & 5.8 & 14.6 & 14.8 & 2.8 & 11.3 \\
\hline
\end{tabular}

Source: $\quad$ OECD National Accounts for Austria, Belgium and Germany; IMF, Government Finance Statistics Yearbook, 2003, for the others.

\section{Box 1. The Fiscal Equalisation Law}

The Fiscal Equalisation Law (Finanzausgleichsgesetz, FAG) is pivotal in defining major inter-governmental fiscal relations. The provisions of the law are negotiated between the federal government, the states and the municipalities and have validity for a period of four years. The most recent update of the FAG came into force in January 2005 . The FAG determines the types of taxes to be shared between the three levels of government (gemeinschaftliche Bundesabgaben) and the proportions according to which the revenues are allocated. It also specifies major transfer flows between the levels of government.

Most important types of taxes are shared taxes (gemeinschaftliche Bundesabgaben), such as personal income tax, corporate tax and value added tax, with the corresponding tax rates determined by federal legislation. The revenues of certain taxes are not shared but are kept by local and state governments according to how much revenue is generated within each state or municipality ("own taxes", ausschließliche Landesabgaben, ausschließliche Kommunalabgaben). These taxes however play a significant role only for the municipalities. The most important tax of this type is the communal tax (Kommunalsteuer), a tax on private enterprise payrolls, the rate of which is determined by the federal government. The FAG also determines which own taxes can be set autonomously by the states and municipalities, respectively. Real estate tax rates are the only significant tax parameter that can be set autonomously by sub-national governments. They are determined by the municipalities subject to a ceiling determined in the FAG.

Tax sharing is achieved in different stages. Distributable tax revenues are obtained after deducting some tax receipts from the total (Vorwegabzüge). These deducted tax revenue shares are earmarked to particular spending items. For example, a proportion of personal income tax revenue is earmarked for the financing of family benefits (Familienlastenausgleich) and is administered by an extra-budgetary fund, the Familienlastenausgleichsfonds. At the second stage the shares of tax revenues accruing to each level of government (federal government, states, municipalities) as a whole are fixed. About $73 \%$ of the revenues of shared taxes accrue to the federal government, the 
states receive $15 \%$ and the municipalities about $12 \%$. Finally, the horizontal distribution of taxes across municipalities and states, respectively, is determined.

The allocation of revenues from shared taxes across municipalities is based on the weighed distribution of population, such that municipalities with relatively many inhabitants receive more revenues per capita, with the percapita weights increasing up to a population of 100000 . The purpose of this rule is to compensate large municipalities for the supply of services that also benefit residents in smaller surrounding municipalities. However, the weight given to large municipalities gradually declined in successive FAG negotiations. In addition, a proportion of $13 \%$ of the municipalities' share in shared tax revenues is allocated via the states, which are required to distribute these funds back to the municipalities through discretionary grants. ${ }^{7}$ These discretionary grants often co-finance investment projects of municipalities but can also be used to provide aid for municipalities in financial distress.

The weighted population key is also applied to the horizontal distribution of tax revenues across the states. Thus, states containing relatively large municipalities receive a larger tax revenue share than states containing small municipalities. In addition, if a state's per capita revenues from shared taxes fall short of the average per capita tax revenues by more than $11 \%$, the difference is equalised by a federal transfer (Landeskopfquotenausgleich).

Up to the most recent revenue sharing arrangement the weighted population key was based on the results of the population census, conducted every ten years. The low frequency of population adjustments resulted in relatively large changes in revenues of sub-national governments. To solve this problem the new FAG, has determined a timetable for continuous updating of population data on the basis of residential registry.

In addition to determining the distribution of shared tax revenues, the FAG also contains rules to reduce inequalities in municipalities' own tax revenues, i.e. tax revenues generated within each municipality and which municipalities keep, notably real estate taxes and the communal tax. The equalisation mechanism is highly complex and has the following characteristics: Municipalities with below-average potential own tax revenues receive vertical equalising transfers from the federal government. Potential tax revenue is, essentially, defined as the sum of weighted per capita revenues from the communal tax as well as imputed real estate tax revenues on the basis of hypothetical (rather than actual) real estate tax rates (Finanzkraft). ${ }^{8}$ Hypothetical real estate tax rates are used in order to prevent incentives for municipalities to set a low tax rate to qualify for more funds through the tax revenue equalisation mechanism. Part of the equalising transfers to the municipalities is provided directly by the federal government, while the other part is channelled through the states. Municipalities must meet eligibility criteria to qualify for the latter transfers. In particular, they have to set the maximum permissible real estate tax rate determined in the FAG. The states provide these funds to municipalities whose Finanzkraft is below the state average. In some states the funds received from the federal government exceed the amount required for this purpose. In this case, the states can distribute the funds according to criteria they determine themselves. ${ }^{9}$ Equalising transfers provided directly by the federal government and transfers provided via the states are interdependent, as the latter are included in the Finanzkraft on the basis of which the direct transfers from the federal government are calculated.

The FAG also allows state governments to impose a levy on the municipalities (Landesumlage) and determines a ceiling for this levy. It is mostly set with respect to the municipalities' Finanzkraft (as defined above) and thus also has a redistributive impact. Most states make use of the opportunity to impose a levy on municipalities. The resulting funds are freely available for state governments.

In addition to the earmarked Vorwegabzüge, a substantial share of the tax revenue shares for sub-national governments as well as many transfers from the federal government to sub-national governments are earmarked to specific spending items. For example, a fraction of the total receipts in shared taxes is earmarked to subsidies for local public transport and to measures to save energy and protect the environment. Some earmarked funds require matched funding of the local government, for example, for states' and municipalities' spending on housing construction subsidies, waste treatment and hospital financing. The federal government reimburses sub-national governments for, notably teachers' pay. 
Table 2. Fiscal decentralisation

\begin{tabular}{|c|c|c|c|c|}
\hline & \multicolumn{4}{|c|}{ Share in general government spending ${ }^{1}$} \\
\hline & \multicolumn{2}{|c|}{ Intermediate level } & \multicolumn{2}{|c|}{ Local government } \\
\hline & $1985^{2}$ & $2003^{3}$ & $1985^{3}$ & $2003^{3}$ \\
\hline Austria & 13.7 & 16.4 & 17.2 & 13.7 \\
\hline Belgium & 20.2 & 22.4 & 12.3 & 13.0 \\
\hline Canada & 47.8 & 52.3 & 10.2 & 10.5 \\
\hline Denmark & & & 53.7 & 58.4 \\
\hline Finland & & & 32.0 & 37.6 \\
\hline France & & & 15.9 & 18.6 \\
\hline Germany & 22.3 & 22.4 & 16.8 & 13.9 \\
\hline Greece & & & 4.1 & 4.8 \\
\hline Ireland ${ }^{4}$ & & & 30.2 & 29.5 \\
\hline Italy & & & 25.4 & 31.0 \\
\hline Japan & & & 44.5 & 39.3 \\
\hline Netherlands & & & 32.6 & 34.8 \\
\hline Norway $^{5}$ & & & 34.6 & 30.6 \\
\hline Portugal & & & 10.3 & 13.4 \\
\hline Spain & 14.4 & 32.7 & 11.1 & 13.0 \\
\hline Sweden & & & 37.1 & 43.6 \\
\hline United Kingdom & & & 22.2 & 27.6 \\
\hline Average of OECD countries ${ }^{6}$ & & & 23.7 & 26.1 \\
\hline
\end{tabular}

1. Excluding the transfers paid to other levels of government. National Accounts data.

2. Or earliest year available: 1986 for Ireland; 1987 for the Netherlands and the United Kingdom; 1989 for Canada, Japan, Luxembourg and Norway; 1991 for Germany; 1993 for Sweden; 1995 for Austria, Belgium, Denmark, Finland, Greece, Portugal and Spain.

3. Or latest year available: 1996 for Ireland, 2000 for Japan, 2002 for Denmark and the United States.

4. Data based on SNA68 methodology.

5. The share in general government revenues is expressed in \% of mainland government revenues.

6. Simple average of federal and unitary countries. The average takes into account only countries for which data are available for both years.

Source: OECD National Accounts database; Statistics Norway; Statistics Canada; US Bureau of Economic Analysis.

\section{Issues in funding across layers of government}

\section{Devolved taxing powers are almost absent ...}

8. Sub-central levels of government rely largely on shared taxes, for which the federal government has full legislative responsibilities, and on federal government transfers. The states have few sources of own tax revenues. About $70 \%$ of the total revenues of the municipalities are made up of shared tax receipts and transfers from other levels of government. About 10\% consist of user fees and $20 \%$ of tax revenues derived from tax bases that are attributed to the municipalities alone ("own taxes"). Since the beginning of the 1990s the share of own taxes in overall revenues declined (Figure 1). At present, somewhat more than half of the municipalities' own tax revenues consist of the communal tax (Kommunalsteuer).$^{10}$ The most important tax for which the municipalities have some discretion in setting taxation (the tax rate) is the real estate tax. Real estate tax revenues account for only $4.5 \%$ of the municipalities' total revenues, ${ }^{11}$ their volume being much smaller than that of the communal tax. By international comparison, Austria also stands at the lower end with respect to utilisation of real estate taxes as a revenue source for sub-central government (Figure 2).

9. In several respects there remains scope to improve the present rules of tax sharing. First, some regional centres with relatively high spending on services serving bordering municipalities are being funded less well than similarly sized municipalities which are not the centre of an agglomeration. ${ }^{12}$ Second, sub-national governments differ in the demographic composition of population, while demand for social, 
education and health care services, which are financed by sub-national governments to a significant extent, is stronger for specific demographic groups, such as the elderly, young children, and immigrants. The provision of services by centres of agglomeration demanded by residents of neighbouring municipalities should be taken into account in the distribution of tax revenues of local governments. The demographic composition of the population, such as the proportion of the elderly, young children and immigrants, should be used as additional criteria for the determination of tax revenue shares of sub-national levels of government.

Figure 1 Composition of tax revenues of sub-national governments, 2002

$\%$ of total revenue

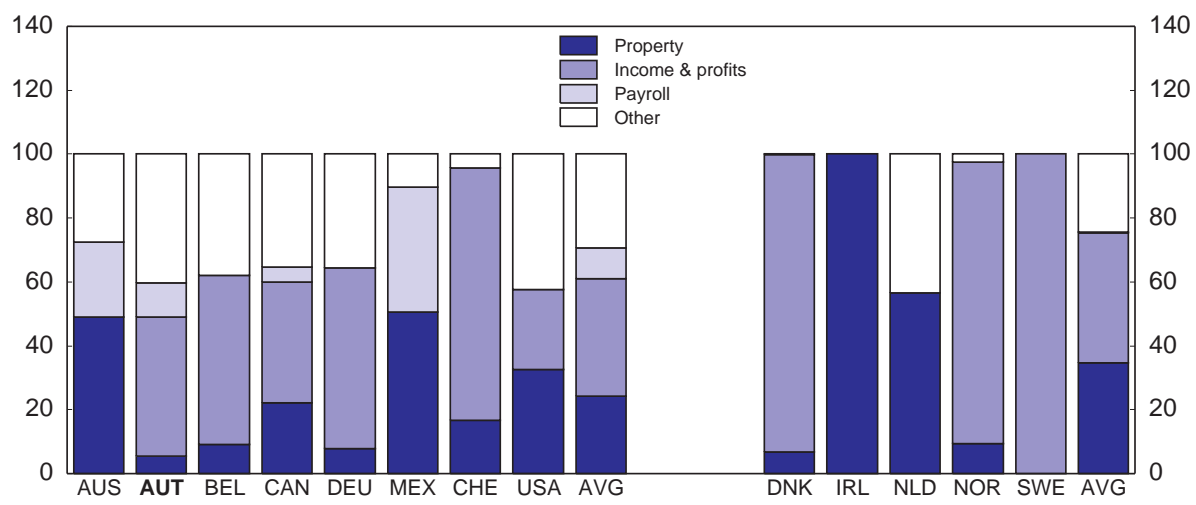

1. Federal countries to the left, unitary countries to the right. AVG is the average of the respective group of countries in the graph.

Source: OECD Revenue Statistics.

Figure 2. Own tax revenues of municipalities ${ }^{1}$

$\%$ of total revenue

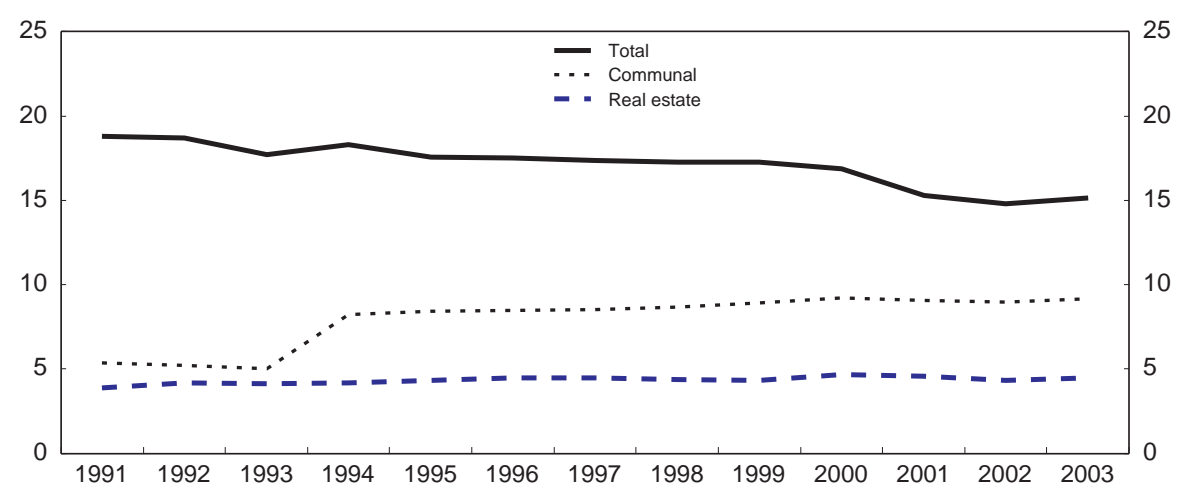

1. Own tax revenues are tax revenues generated within each municipality which each municipality can keep.

Vienna is excluded. Total revenues are administratively defined and include some financial transactions, such as the repayment of loans.

Source: Statistics Austria. 
10. Moreover, the share of taxes which sub-national governments can set is very low in international comparison, given that the real estate tax of the municipalities is the only major item of this type. If subnational governments had to rely more on tax revenues under their own control, the congruence between sub-central spending and taxation would be improved and become more transparent for the electorate, reinforcing social choice and fiscal discipline. In addition, a large proportion of municipalities' and states' tax and transfer revenues are earmarked to specific spending programmes according to uniform rules across all states or municipalities (see Box 1), which further limits the extent to which the regions can take differences in local preferences into account.

11. Thus, economic benefits of increasing the scope of state and local governments in levying own taxes at the expense of intra-governmental transfers and co-financing are likely to be significant. However, up to date valuation of real estate is a precondition for strengthening revenue-raising powers of municipalities on the basis of real estate taxes. The valuation of the tax base falls short of market values by large margins. Revaluation of real estate for tax purposes, which is the responsibility of the federal government, is conducted infrequently, the last one dating from $1973 .{ }^{13}$ Low valuation of agricultural land is also maintained in order to provide support for agricultural activity.

12. The parameters of the communal tax are determined at the federal level. It appears appropriate that the tax rate is set centrally as business payroll tax rates set by local governments could induce some municipalities to raise tax revenue at the expense of residents of other municipalities and distort firms' location decisions. The tax gives the municipalities some incentives to develop their tax base as revenues generated from the tax accrue to the municipalities where employing firms are located. However, most core public services provided by sub-national governments serve resident individuals (in particular education, health care and social welfare, see also Table 1 above) ${ }^{14}$ Hence, the communal tax might only weakly match spending needs on local government services, especially in view of the small size of most municipalities in Austria (see below). The new FAG enables municipalities to share communal tax revenues with each other, for example, if several municipalities contribute infrastructure investment for attracting enterprises. While the new rule is likely to improve incentives to attract business activity spanning across municipalities' borders, it does not address the geographic mismatch of spending needs and communal tax revenues. It is another draw-back associated with the communal tax that many municipalities appear to reimburse new firms for their communal tax liabilities, undermining the federally set uniform tax rate. ${ }^{15}$ De facto tax competition through such reimbursements reduces transparency of the tax burden.

13. Relying more on revenues generated by the real estate tax is likely to be the most favourable option to develop the taxing power of the municipalities. The tax base is not mobile geographically and less cyclically volatile than other tax bases. The latter aspect is of particular importance with respect to Austria's domestic Stability and Growth Pact, which obliges the municipalities to prevent a deterioration of their fiscal balances below a certain threshold. Moreover, since the quality of local services is reflected in real estate values, real estate taxes raised by sub-national governments also strengthen incentives to improve service provision. The low share of real estate tax revenues by international comparison illustrates the scope to increase utilisation. Moreover, revaluation of real estate for taxation purposes in line with more up-to-date market prices would reduce the distortions inherent in the current valuations. The present unrealistic valuation of real estate distorts economic activity as real estate whose value has risen most strongly since the latest valuation is taxed more favourably than real estate which has risen slowly in value. Lower valuation of agricultural land should not be used as an instrument to subsidize agriculture. Hence, valuation of real estate for tax purposes should thus be updated more frequently, taking into account the administrative cost of revaluations, and valuations should be unified across sectors in line with market valuations. 
14. On the level of the states, consideration should be given to introducing genuine taxing powers that replace the states' levy on the municipalities. Allowing the states to incorporate a surcharge into the lowered - income tax schedule would be an option. Levying an income tax surcharge on residents would be broadly in line with taxing the beneficiaries of services provided by sub-national governments as the states serve their residents in a variety of areas (see above). Also, limiting states' discretion to the right to vary the rate of taxation, rather than the tax base, minimises compliance and administrative costs. However, strong income taxing powers of sub-central governments are associated with negative externalities on other constituencies. In particular, too high a taxation might cause the overall tax base to shrink and can weaken the redistributive role of federal income taxation. Limiting such adverse effects suggests confining the right for sub-central income taxation to setting a flat tax rate subject to a corridor whose width is to be determined by the federal legislator. While several OECD countries allow sub-national governments to set income tax rates, some countries, such as Norway and Iceland, introduced constraints of this type. ${ }^{16}$

\section{... while earmarked revenue allocation and co-financing go too far}

15. A substantial proportion of shared tax revenues and federal government transfers accruing to the states and local governments are earmarked to finance particular sub-national spending items. Many of these transfers are determined in the fiscal equalisation law (FAG) (see Box 1). Overall, earmarked revenues, net of additional cost sharing and transfer arrangements between state and local governments, account for about a third of the states' revenues and a half of the municipalities' total revenues. ${ }^{17}$

16. The large role of earmarked revenues for sub-national levels of government increases the complexity of federal fiscal relations substantially. Moreover, co-financing of spending items between the states and the municipalities occurs in both directions. For example, municipalities contribute to the financing of social spending of the states and the states co-finance expenditure of the municipalities on childcare facilities. The complexity of the tax sharing and transfer system overall renders the financing and delivery of services very non-transparent, reducing accountability to local voters. The lack of accountability, in turn, makes it difficult to assess the economic impact of resource allocation, impairing effective utilisation of resources. ${ }^{18}$ At the same time, administrative costs associated with earmarked funding were found to be substantial, arising from application procedures involving potential beneficiaries, establishing evidence that funds were used as approved, and related activities. Costs relative to the size of the funds extended appear to be particularly high for small municipalities where they were estimated to reach between 10 and $20 \%$ of the transfer volume. ${ }^{19}$ Moreover, federal government co-financing of subnational spending items can generate inefficient resource allocation as it generates a wedge between the budgetary costs of the sub-national authority and the full costs of the spending project.

17. Earmarking tax revenues to spending is also likely to distort the tax and spending structure, as changes in the revenue from particular taxes may differ from appropriate changes in spending. The Family Burden Equalisation Fund (Familienlastenausgleichsfonds, FLAF) stands as a major example of revenue earmarking contributing to incentives to expand spending.

18. Co-funding by the federal government and the states of investment for the purpose of waste water treatment has contributed to substantial inefficiencies in waste water networks, due to the development of settlements, mainly in the rural areas of Austria. Co-funding has also established a hurdle for abolishing subsidies for residential construction. Under the Wohnbauförderung (WF) scheme, the federal government provides earmarked funding to the states to subsidise residential construction. The states allocate the subsidies and provide matched funding. Most of the total funds are extended in terms of interest rate subsidies and annuity support for loans. Up to 1997 the volume of funds disbursed to states for this purpose was rising quickly, and cumulated claims out of granted credits amounted to $€ 20.5$ billion, indicating the high volume of resources channelled into residential construction. More recently some states have 
capitalised their claims to contain their debt. To contain the rising fiscal burden on the federal budget, federal transfers to the states were capped from 2001 onwards, and earmarking was relaxed by allowing the states to use part of the overall funds for other uses, notably reduction of greenhouse gas emissions and improvements in infrastructure. ${ }^{20} \mathrm{Up}$ to now most of the subsidies for housing have been spent on new construction, and a smaller portion (some 11\%) is used for renovations of the existing housing stock.

19. While the WF has been repeatedly under debate, it was placed outside the sphere of negotiable items in the recent re-negotiation of inter-governmental revenue sharing, indicating the difficulties associated with scaling down earmarked schemes of inter-governmental funding. Whether the scheme is effective with respect to social redistribution goals is questionable as low-income families who are not owners of residential property bear part of the tax burden to finance the WF. The WF constitutes a subsidy for the construction industry, effectively diverting resources away from more productive allocations. In the same vein, the subsidies have favoured substitution of newly constructed for already existing real estate. Moreover, while residential investment rates in Austria were large by international comparison, in recent years the residential construction sector has been subject to over-capacity and rapid population ageing in the years to come is likely to be associated with falling demand for residential units in the long term. This is aggravated further with respect to infrastructure requirements. Earmarked federal government funding for residential construction subsidies disbursed by the states should be phased out.

20. The WF funds can also be used by the states to subsidise expenditures which increase the energy efficiency of new or existing housing. However, these subsidies are unlikely to be the most efficient way to achieve reductions in greenhouse gas emissions. First, it is difficult for the federal government to ensure that the states and the ultimate recipients of the subsidies make use of the subsidies in the most effective way. Second, the emission-reducing impact of the subsidies is likely to be partly offset as a result of households choosing higher ambient temperatures, as the subsidies effectively reduce heating costs. Third, there is a risk that the subsidies might reduce the private marginal cost of abating pollution in residential heating below the private marginal cost of abating pollution from other activities (e.g. transport), thus diverting abatement effort in other activities where such efforts would be less costly. A more efficient way to achieve greenhouse gas emission targets would be to rely on price mechanisms, such as higher taxes on heating fuel.

21. The federal government distributes earmarked grants to municipalities and state governments for public transport spending, amounting to about $€ 200$ million in 2003. Part of the grants is allocated according to the length of the transport network relative to the number of passengers, ${ }^{21}$ mitigating incentives to increase revenue through increasing passenger numbers. Until recently the volume of transfers was linked to some share of mineral oil tax revenues. Consequently, past increases in the mineral oil tax reinforced the adverse incentives.

22. Earmarking of tax revenues should be given up, and extra-budgetary funds should be fully integrated into the budget of the respective government. Co-financing should be strictly limited to cases where clear externalities are present and local provision is nonetheless preferable, and should be based on output rather than input indicators.

\section{... with the overall redistribution system implying inefficiencies}

23. Austria's system of revenue allocation yields a substantial redistribution of income across regions designed to reduce dispersion in living standards. As depicted in Table 3 transfers by the federal government - based on the provisions of the FAG (see Box 1) - to compensate municipalities with small own tax revenues imply a strong reduction in inequality as measured by the ratios of the highest to the lowest revenue quintile. Indeed, the large number of different transfers contributing to redistribution and their complexity make it very hard to assess the degree of the compensation effects faced by individual 
municipalities. On average, the municipalities are estimated to lose $55 \%$ of their own tax receipts due to inter-governmental revenue redistribution. Compensation effects are substantially higher among the poor municipalities, which are recipients of equalisation transfers, totalling more than $100 \%$ in some cases. ${ }^{22}$

Table 3. Redistributive effect of the tax sharing and transfer arrangements

\begin{tabular}{lcc}
\hline $\begin{array}{l}\text { Quintiles of municipalities, by own tax } \\
\text { revenues per capita }\end{array}$ & Own tax revenues & $\begin{array}{c}\text { Revenues from taxes } \\
\text { and transfers }\end{array}$ \\
\hline 1. quintile & 87 & 695 \\
2. quintile & 140 & 686 \\
3. quintile & 199 & 683 \\
4. quintile & 286 & 790 \\
5. quintile & 525 & 1096 \\
Ratio $^{\text {th }}$ to $1^{\text {st }}$ quintile & 6.03 & 1.58 \\
\hline
\end{tabular}

1. Including shared taxes and own tax revenues.

Source: Schönbäck et al. (2003).

24. The redistribution mechanism should be simplified and made more transparent, reducing compensation effects on own tax revenues below 100\%. The present complex equalisation system could be replaced by a system of horizontal transfers among municipalities at the level of each Land, supplemented by grants of the federal government to relatively poor states, which the states distribute to municipalities.

\section{Issues in the allocation of spending responsibilities}

25. The assignment of regulatory powers by government level is an important determinant for the quality and efficient provision of public sector goods. Provision of services at sub-central levels of government can promote allocative efficiency and allows local preferences to be taken into account. However, in several respects the conditions for decentralised provision of services to be beneficial may not be met. Often spillovers across regional boundaries or the existence of scale effects suggest more centralised service provision. Moreover, without clear evidence in favour of decentralisation, regulations and income redistribution at the sub-national levels can lead to market segmentation that hampers the economy's potential to generate income and employment. For example, in Austria the states are responsible for the definition of skill profiles in certain occupations such as long-term care. This has led to a fragmentation of the labour market which reduces labour mobility and makes these occupations less attractive, ultimately restraining employment opportunities and pushing up the costs of service provision. ${ }^{23}$ Fragmentation has thus contributed to a shortage for long-term care personnel.

26. On a related count, dispersed assignment of regulatory powers may increase the need for intergovernmental co-ordination. The need to reach consensus among all parties might prevent regulation from being modified quickly enough with changing circumstances. This section highlights areas where a re-assignment of spending and regulatory powers might yield substantial efficiency gains in the provision of public sector services.

\section{Cost-sharing in service provision needs to be developed}

27. Many municipalities in Austria are very small, with more than half of all municipalities counting less than 5000 inhabitants (see Figure 3). The number of municipalities has even increased over the last 25 years. Municipal administrative costs per capita in Austria are highest in the smallest municipalities and decline as the population of municipalities increases, up to about 5000 inhabitants $^{24}$ (see Figure 4). Outlays for primary schooling stand as an important example for high fixed costs, as municipalities cover 
the salaries of non-teaching staff as well as investment costs. ${ }^{25}$ Administrative costs in municipalities with 5000 inhabitants are about $40 \%$ lower than in the smallest municipalities. Administrative costs per capita rise again as the size of the municipality increases beyond a population of 10000 , but this reflects the tendency for larger municipalities to take on central administrative functions which also cover neighbouring municipalities. Digressiveness of costs per inhabitant over a wide range of population size originates from fixed costs and is in line with international evidence. ${ }^{26}$ High fixed costs among small municipalities appear to have contributed to increasing indebtedness, as small municipalities have experienced a significantly bigger increase in indebtedness than larger municipalities.

\section{Figure 3. Distribution of municipalities by resident population}

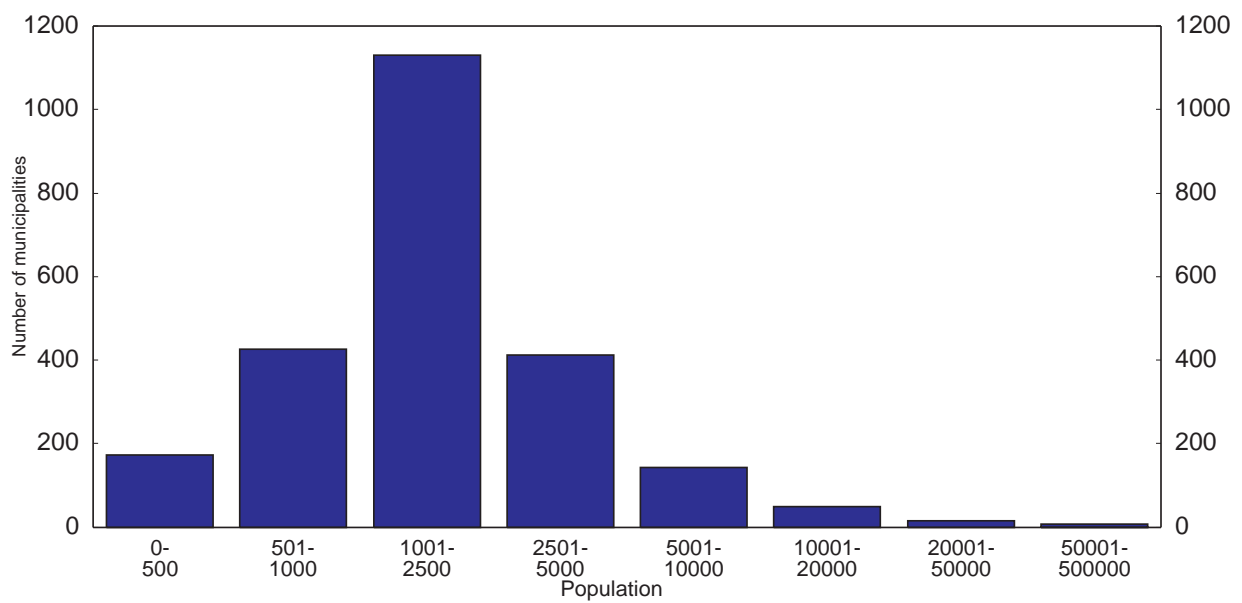

Source: Austrian Municipal Association.

28. The weight of fixed costs in administrative costs has further increased recently, as a result of increased use of information technology ${ }^{27}$ Hence, there is a need to exploit returns to scale of community size in the provision of government services to control costs and debt accumulation and to deal with future fiscal demands originating from population ageing. From the economic perspective, merging municipalities would be a preferable option as mergers allow the benefits of increasing returns to scale to be reaped while preserving accountability to local voters. Some countries within the OECD merged local authorities to achieve cost savings. For example, Denmark is planning to reduce the number of municipalities from 271 to about 100 , which will raise the general minimum size of a municipality to 20000 . Smaller municipalities which do not wish to amalgamate are obliged to enter co-operation agreements with other municipalities. ${ }^{28}$ Consideration should be given to merge small municipalities where this would result in cost savings. 
Figure 4. Spending and debt by municipality size class
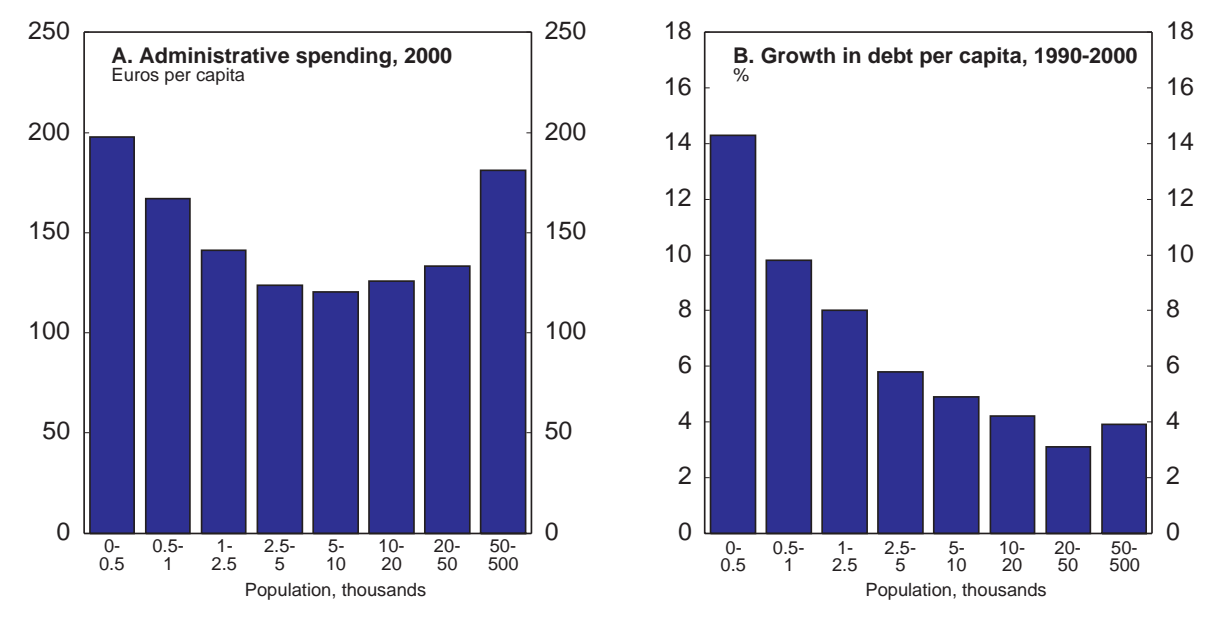

Source: Statistics Austria and WIFO.

29. Widening co-operation between municipalities through the joint provision of services is a second option. Examples include the sharing of the capital stock used in the production of services, such as transport equipment, or the sharing of administrative services, such as the management of municipalities' property. ${ }^{29}$ Joint provision among local authorities in Austria has spread in recent years, notably with respect to the provision of schooling, administration of social assistance and hospitals. There is evidence that municipalities were able to reduce the costs of schooling per inhabitant via joint provision of schooling facilities. ${ }^{30}$ Nonetheless, legal hurdles still limit the extent to which municipalities can provide services jointly. In particular, municipalities have thus far not been able to create associations across state borders. Indeed, each state has so far determined its own rules on the organisation of associations. Agreement was reached in the constitutional convention (Österreich Konvent) to give more scope for the creation of associations of communities, allowing them to cover municipalities of various states. To this end, reform proposals of the constitutional convention foresee that legal rules regulating the institutional structure of associations can also be set in agreements between the federal government and the states. Such steps would mark progress towards reaping the benefits of increased co-operation. The consensual nature of agreements between the federal and state governments may however limit the extent to which any new institutional rules determined in such agreements may create room to foster such cooperation. Legal hurdles for the creation of associations should be removed. It should be ensured that the creation of associations across the borders of states is not hampered by requirements to reach consensus between the federal government and the states.

30. Experience from some OECD countries suggests, however, that the benefits of joint provision among municipalities need to be weighed against potential losses in accountability to local voters. To increase transparency local authorities could purchase services from each other. This requires transparent cost-accounting to be in place for prices to be determined. Such purchaser-provider relationships among municipalities are an option to the extent that it is feasible to exclude the non-providing municipality from the benefits of the service, as for example waste disposal. For all these options it is true that replacing discretionary grants from state governments by higher local autonomy to set tax rates and introduce user fees would strengthen cost-awareness among administrations. 


\section{Fragmented decision making needs to be reduced}

\section{Disaster prevention involves federal and local government}

31. In August 2002 the most serious floods for more than 100 years touched large regions north of the Danube and caused damage of about $2 \%$ of GDP. Many areas were not prepared for a catastrophe of this kind and the magnitude of individual losses required large scale compensation efforts from public budgets. An analysis of hydrographical trends argued that the likelihood of floods increased. A thorough analysis of the 2002 flood $^{31}$ shows that scope for protection against natural disasters is limited. A number of conclusions have been drawn by the experts participating in this project, mainly emphasising passive flood prevention, measures in the catchment area, retention measures and nature-near structural protection measures. The government has also made clear that regional and local hazard zone plans have to be redesigned. This is a competence of the states, which have finished this task for about $65 \%$ of municipalities. The new plans identify not only areas at high risk, but also retention areas. Such areas are to be kept free of buildings and transport infrastructure. Past experience shows that natural disasters lead to significant budgetary costs. Measures which would contain the impact of future natural disasters would also curb such costs. The government should therefore make sure that the measures outlined in a big interdisciplinary flood study are also implemented by the responsible lower levels of government. Conditioning part of federally provided transfers on compliance with appropriate flood risk prevention measures could enhance efforts in the right direction.

\section{Social assistance}

32. Over the last decade or so labour market policies of the federal government have gradually given a larger role to measures designed to activate the unemployed. Developing this approach into a coherent strategy requires that disincentives for labour force participation and employment associated with the provision of social assistance benefits $(\mathrm{SH})$ be addressed as well.

33. SH is subject to legislation by the states, and is financed by the states, with benefits generally administered by associations of municipalities, while unemployment insurance benefits are financed and administered by the federal labour office. SH for income support is means-tested and paid to all persons, working or not, whose income from other sources falls below a certain subsistence level. Those who are able to work are in principle obliged to accept employment to be eligible for SH benefits and have to be registered as unemployed. Recipients who refuse to co-operate might face sanctions. By the end of 2002 benefits were extended to some 91000 persons living in households, including supported family members. The states' regulations differ with respect to eligibility conditions, the generosity of benefits and modes of organization and financing. Local administrations have some discretion with respect to executing the law. At present the decentralisation of the social assistance system is associated with a number of shortcomings that warrant improvement.

34. First, statistical information on recipients of social assistance is deficient in several respects. Data delivered to the Statistics Office mainly contain information on the stocks of persons or number of episodes associated with aid within a given year, while information on the duration of support and on socio-economic characteristics of the recipients such as age, marital status and education is lacking. Hence, published information does not even allow judgment on basic characteristics such as to what extent support accrues to persons of working age or other age groups. More specifically, the lack of suitable statistical information is rendering analysis of the impact of income support and labour market policies on labour force participation and transitions into and out of employment almost impossible. In the same vein, statistics are not harmonised across states. Some states record only persons receiving permanent income support as opposed to one-off payments, and the definition of permanent support varies across states, ranging from a few months in some states to half a year or a year in others. ${ }^{32}$ Data comparability is further 
reduced by the regions' discretion on whether or not social assistance is granted in terms of one-off or permanent transfers.

35. Second, dispersed responsibilities across sub-national governments go along with a lack of coherence between income replacement and activation policies that are likely to reduce incentives to accept employment. In principle, receipt of social assistance is conditional on the recipients' willingness to accept employment. However, eligibility standards appear to vary widely across both states and regions. Often, social assistance is granted on a one-off basis, associated with less stringent assessment of work availability, even if receipt of social assistance is not temporary. Efforts to monitor job search activities of social assistance recipients differ across jurisdictions, which may have contributed to variations in the number of SH recipients relative to the level of unemployment across sub-national jurisdictions.

36. Third, some share of $\mathrm{SH}$ recipients simultaneously receive unemployment assistance (Notstandshilfe, $\mathrm{NH}$ ), which also provides means-tested income replacement for unemployed persons whose eligibility for receipt of unemployment insurance benefits is exhausted. While both types of benefits are of potentially indefinite duration, $\mathrm{NH}$ is extended at a fixed replacement ratio of previous earnings and is administered by the PES. The share of long-term unemployed who receive both types of benefits simultaneously still appears to be relatively small, but there is some evidence that simultaneous claims increased significantly in recent years. Since the share of part-time and a-typical employment contracts is increasing, social assistance benefits that top up income replacement provided by the PES are likely to gain further importance. Moreover, the increasing number of older workers, who are subject to a higher risk of long-term unemployment than other age groups, may raise simultaneous take-up of $\mathrm{SH}$ and $\mathrm{NH}$ in the future. The dichotomy of the two means-tested systems is likely to be associated with inefficiencies. The fact that means-tested benefits, based on different rules, are processed by two different layers of government increases administrative cost. It also raises the bureaucratic exposure of recipients of both types of benefits who need to deal with two separate administrations. Also, each layer of government only bears part of the budgetary costs of means-tested support for the unemployed, which could have a negative impact on placement efforts by both the labour office and the municipalities.

37. Moreover, the mode of financing SH poses disincentives for recipients to pick up employment, which appears to be inconsistent with activation policies followed by the PES. In general the states claim back SH benefits from former recipients after they have found employment and once their earnings exceed a certain threshold. This regime reflects the fact that social assistance is considered to be a source of income replacement of last resort and serves as a financing instrument at sub-national government levels. This practice leads to very high marginal effective taxation of earnings, on top of the one that is induced by the withdrawal of benefits when employment is accepted. ${ }^{33}$

38. Social assistance and unemployment assistance for recipients who are able to work should be combined into one means-tested income replacement scheme, removing the inefficiencies associated with the separate provision and financing of the two means-tested benefit systems. To overcome the lack of coherence between income replacement and activation measures, responsibility for the financing of social assistance payments should be moved to the federal government, with the federal employment office in charge of disbursing the benefits. This assignment of responsibilities would allow to more effectively combine benefit payment with the monitoring of job search by all unemployed. Also, social assistance benefits should not be reclaimed by the states so as to lower the effective taxation of earnings. To reduce incentives to pick up social assistance payments in the first place means testing and work availability testing should be strict. 


\section{Health care}

39. While Austria enjoys the highest self-reported satisfactions levels with health care services among EU countries and nearly universal coverage of health care services, a number of fiscal federal issues arise. Responsibilities in funding and financing of health care are fragmented, particularly in the hospital sector, involving the federal government, the state governments, the municipalities and social health insurance. In addition, health care services provided by hospitals and outside the hospitals by practicing physicians have been managed separately. ${ }^{34}$ At the same time, defined quality standards have been missing.

40. While the proportion of GDP devoted to health care spending in Austria-7.7\% of GDP in 2003 - appears moderate, health care costs may be underestimated by $1.8 \%$ of GDP. ${ }^{35}$ Incomplete statistical coverage of the states' financing of hospital deficits contributes to the underestimation of healthcare spending. ${ }^{36}$ Details of the states' financial contributions to hospitals are not made public in all states and some states have reclassified subsidies they provide to hospitals as loans, rather than transfers, in recent years. ${ }^{37}$ Implementation of the OECD system of health accounts is expected to improve data transparency as well as the international comparability of Austrian health care spending data in the near future.

41. According to the social insurance association, the social health insurance finances $39 \%$ of total spending on hospital-provided services, with the states and municipalities contributing $35 \%$ and the federal government $9 \% .^{38}$ Most contributions to finance services provided by the government-funded hospital sector are pooled in state-level off-budget health care agencies which manage hospital financing (Landesgesundheitsfonds, LGFs ${ }^{39}$ ). The funding contributions of the federal government, social health insurance and states to the LGFs are determined in an agreement between the federal government and the states. Some states, however, provide additional funds, in part outside the LGFs, mostly to cover deficits of hospitals within their territory, as the contributions to the LGFs agreed by the federal government, social health insurance and the states are subject to budget ceilings. ${ }^{40}$ While the funds disbursed by the LGFs are distributed across hospitals according to a national system of diagnosis-related groups (DRGs), states are free to distribute their additional funds according to criteria they determine themselves. Investment spending is born separately by the hospital owners, mostly state and local governments.

42. While the states finance less than half of the government outlays for hospital services, the states play a dominant role in decision making for hospital services (see Box $2^{41}$ ), reflecting the assignment of health care policy responsibilities in the constitution. This is likely to weaken incentives to achieve cost reductions in hospital services, as state governments may have an interest in maintaining hospital capacity in their state, but only face part of the cost of doing so, which is likely to reduce incentives to cut excess capacity and take advantage of increasing returns to scale. Hospitals do not face a hard budget constraint, which dulls incentives for cost reduction stemming from the DRGs. In addition, to the extent that statefinancing of deficits compensates cost differences across states, cost-saving incentives from the DRG system are weakened. Some states also split contributions needed to cover spending overruns with municipalities, reducing incentives for cost-effectiveness. ${ }^{42}$ 


\section{Box 2. Hospital financing: the new agencies for health}

A new system of health care agencies at the federal and state level, introduced in 2005, is in charge of implementing health care policy in both the hospital sector and the sector of practicing physicians as well as channelling financial flows to providers in both sectors for selected projects.

The new federal health care agency (Bundesgesundheitsagentur, BGA), is in charge of the planning of health care supply for all stationary and ambulatory services, setting up indicative budgets, setting quality and accounting standards, further development of remuneration systems and fostering health promotion. For example, the BGA is in charge of developing a proposal to reform the remuneration of services which have been generating incentives to shift patients to stationary treatments.

The new state health care agencies (Landesgesundheitsfonds, LGFs), implement guidelines of the Bundesagentur in these policy areas at the state level. The LGFs also take decisions which are binding for both the states and the social security association and take over the role of the former Landesfonds, pooling the financial resources from the social health insurance, the federal government and the states for hospital funding. Failure to implement guidelines of the BGA can lead to the withholding of funds to the LGF, up to $1.6 \%$ of total inpatient care spending.

The LGFs are also in charge of designing projects to improve the coordination of services between the ambulatory and the stationary sectors. 1\% of the LGF's funds are earmarked to such projects ("reform pool") in 2005 and 2006 , rising to $2 \%$ in 2007 . The respective state and the social health insurance have to agree on these projects which are required to benefit both parties financially. Thus, the "reform pool" should, for example, compensate the social health insurance financially for the shifting of treatments from the hospital sector to practicing physicians. The social health insurance remains in charge of contracting and paying for services provided by practicing physicians, but has to follow guidelines set by the federal and state health agencies, for example, on the number of doctors who can contract services with the health funds.

The BGA and LGFs include representatives of the main players in health care service financing: health funds, the federal government and state governments, as well as representatives of the patients' and doctors' associations. While the federal government will have a majority of votes in the federal health agency, consensus is generally required. Moreover, all matters that affect hospitals require the approval of the states, while matters concerning the practicing physicians require approval of the social health insurance. In the LGFs, the respective states have a majority of votes on decisions on hospital-provided healthcare services, while the social security association has a majority concerning decisions on care outside the hospital sector.

43. While mixed responsibilities characterise financing of the hospital sector, the funding of service provision by practicing physicians is in the hands of the social security system, which sets up the contracts with doctors' associations. Remuneration systems in both sectors have thus evolved separately, generating incentives to shift services for patients treated by hospitals to practicing physicians, and vice versa, resulting, in some cases, in the duplication of medical interventions. ${ }^{43}$

44. While take-up of services of practicing physicians - as measured by the number of patient visits per population - is moderate in comparison to other OECD countries, the hospital caseload in Austria is the highest among all OECD countries and recorded substantial increases in the years following the introduction of DRGs in 1997..$^{44}$ The large hospital caseload is in part explained by the large acute-bed capacity interacting with the DRG system. While the introduction of DRGs in hospital financing helped to bring about a substantial fall in the duration of hospital stays, helping to slow the rapid rise in hospital care expenditure, high hospital capacity has exacerbated incentives for health care providers to maximise hospital admissions which typically result from DRG financing systems, thus undermining cost-reducing effects of DRGs. ${ }^{45}$ Moreover, Austria has made less progress in reducing acute care beds than other countries with high hospital capacity (see Figure 5). Indeed the federal audit court, among others, has noted significant overcapacity, suggesting that hospital services to the tune of $€ 3.8$ billion (about $1.7 \%$ of GDP) should be shifted from the hospital sector to practicing physicians. The social insurance association estimates that between 30 and 40 hospitals in Austria should be closed on both medical and economic grounds, as advantages from increased specialisation and increasing returns to scale of hospital size for both costs and quality of care may not be fully utilised in some cases. Moreover, hospital outputs, 
measured according to DRG points, could possibly be achieved at substantially less input costs, according to recent studies. ${ }^{46}$ Fragmented decision making in health care financing and spending responsibilities has thus contributed to the fact that efficiency reserves in the hospital sector have not been fully exploited and that the allocation of service provision across the various health care providers leaves room for improvement.

Figure 5. Hospital capacity

Acute care beds per 1000 population ${ }^{1}$

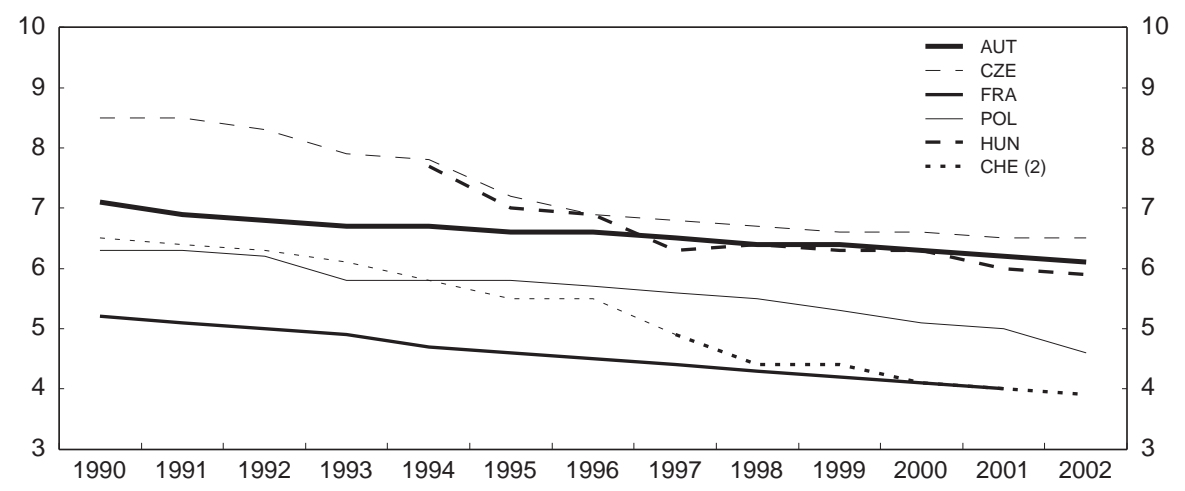

1. Refer to source for details of concept variations across countries.

2. Break 1996/1997 due to implementation of a new system of hospital statistics.

Source: OECD Health Data 2004, 3rd edition.

45. To raise efficiency in health care provision, the government has launched an initiative to overcome fragmentation in health care financing and spending. In particular, the LGFs, created in 2005 on the basis of an agreement between the federal government and the states, bring together the government institutions involved in health care financing and have been given the task to co-ordinate health care service provision across hospitals and practicing physicians (see Box 2). The assignment of responsibilities to the different government institutions and the funding has largely remained unchanged, however.

46. The new LGFs can issue guidelines which are binding for both the social health insurance and the states, marking progress in bringing together disparate decision-making powers on hospital-provided health care services and services provided by practicing physicians. However, the approval of each state is still required for any decisions regarding the hospitals in its territory, while states continue to finance only part of the outlays for hospital-provided services. In addition, the states have been given some share of decision-making on the provision of services by practicing physicians, which they do not finance, which adds to split decision-making and financing responsibilities on health service provision. Consensual decision-making among the various institutions involved in the health care agency system may slow progress in health care reform. New earmarked funds for fostering coordination between the ambulatory sector and the stationary sector are unlikely to be a substitute for an efficient assignment of responsibilities.

47. Sub-national levels of government should not be able to block hospital supply planning decisions unless they are fully in charge of paying for hospital-provided health care services. Indeed, it should be possible to close hospitals which under-perform quality standards. More fundamental reform should aim at assigning financing and spending responsibilities for both the hospitals and practicing physicians to one government institution, giving it the role of purchaser of health services. To this end the health care agencies could be developed further to purchasers of all health care services, including services provided by practicing physicians. The health care agencies would have to be placed in the responsibility of only 
one level of government which should also be in charge of financing the agencies in full. Economies of scale in the hospital sector, in particular, suggest that the federal government level would be best suited for this task. Assignment to the states may be feasible if the agencies can purchase hospital services across the borders of the states, but would also require that the states raise substantial own tax revenues to ensure cost-effectiveness. An alternative option for reform would be to assign financing and spending responsibilities for both health care sectors to social health insurance.

Programme management in environmentally sensitive areas can be improved

48. Austria is continuing to provide considerable resources for improving sustainable development. With $2.4 \%$ of GDP pollution abatement and control costs are the highest among the OECD member countries providing such data. ${ }^{47}$ Performance is in general good, however it is not always clear how this relates to spending, suggesting that there is scope to improve the efficiency of resource allocation for programmes aiming at supporting sustainable development.

49. In April 2002 the Austrian Federal Government adopted a National Strategy for Sustainable Development identifying 20 key objectives covering social, economic and environmental dimensions of sustainable development. Implementation is based on annual work programmes. Progress is monitored along 48 indicators and published in annual reports. An external evaluation is planned. This framework promises to deliver a high degree of policy integration on the level of individual programmes, although coverage is not yet complete (Box 3) and prioritisation and cost efficiency is not guaranteed. While the wealth of information provided in the progress and indicator reports is commendable it is not possible to link progress to individual programmes or the interaction of programmes. While the data underlying the indicators have in general been compiled only since 2003, the indicators are already used for international comparisons to some extent. No attempt is made yet to benchmark best practice or programme targets. No mechanism is available to deal with conflict cases, which could help prevent lengthy court proceedings. The annual implementation reports should contain an explicit statement about the main indicator changes to be achieved by individual programmes. The terms of reference for the evaluation of the overall strategy should include an explicit request to assess the cost effectiveness of individual programmes. Future prioritisation of programmes should take cost effectiveness explicitly into account. A mechanism should be put in place within the National Strategy for Sustainable Development which would allow the reconciliation of the different dimensions of sustainable development before the start of supra-regional projects. Indicator reports should include benchmarking information, which would allow a comparison of how Austria fares with respect to programme efforts and international best practice performance. 


\section{Box 3. The Semmering Tunnel}

\section{An example for missing policy integration across different levels of government}

A headline example of missing policy integration of different sustainable development goals is the decade-long conflict over a tunnel, which would shorten rail-travel time between Vienna and the southern states of Carinthia and Styria by about half an hour. The project volume is about $€ 1$ billion, of which about $€ 100$ million have been spent already. The government of Lower Austria opposes the project because of local nature protection concerns while the governments of Styria and Carinthia together with the federal government support the project for economic and transport policy reasons including enhanced opportunities to shift transport volume towards the less environmentally damaging rail transport. The current railtrack over the Semmering is not fit for big containers and rapid trains. Hence transporting goods and persons between Vienna and the southern states of Carinthia and Styria mainly runs on roads. The basic issue is that a supra-regional project can be blocked on the grounds of local concerns, which obviously are not consolidated on a higher level.

The project made multiple preparations necessary, was started, but is now on hold because of a natural protection decree of the state government of Lower Austria, rejecting the project:

First the rail track between Vienna and the Italian border was declared a high performance track by a decree of the federal government.

Second a law concerning the financing of the tunnel project passed the federal parliament.

Third a decree of the minister of transport charged the high performance rail track company $(H L-A G)$ with the realisation of the project.

1989 Start of planning phase.

1990 Positive assessment of the environmental impact of the project.

1991 Choice of the track by decree (out of 19 alternatives).

1993 Economic analysis of the project by an external consultant (Prognos AG) demonstrates the project to be preferable relative to alternatives (renovation of the 150 year old track, construction of a new track without a tunnel).

1994 Final permission by the highest rail track authority after hearing all concerned federal and local government authorities and after consideration of all public (including environmental) interests.

1994 Start of construction works.

1994 Start of the natural protection proceedings under the jurisdiction of the state of Lower Austria.

1999 The Austrian Constitutional Court (Verfassungsgerichtshof) confirms that the competence in issues of natural protection is with the states - even concerning rail track construction, which is a federal competence - but that the states have to consider supra-regional matters when issuing a decree in this area.

2000 Stop of construction works after a negative natural protection decree from the government of Lower Austria.

2001 Second negative nature protection decree concerning the project.

2003 The federal parliament passes a motion to encourage the federal government to implement its decisions concerning the construction of the Semmering Tunnel.

2004 The high administration court (Verwaltungsgerichtshof) rejects the negative natural protection decree because of an excessive interpretation of competences. The state of Lower Austria is asked to repeat the natural protection examination.

2004 The government of Lower Austria solicits new expertise, which argues that 12 out of 14 swamps would be endangered if the construction of the tunnel were continued.

50. Decisions about the right policy mix in many environmentally sensitive areas involve complex cost considerations and multiple objectives. Fragmentation in this respect may occur because decision makers are only aware of parts of this complex set of constraints, costs and objectives. Developing appropriate support tools may involve considerable fixed costs and might not be worthwhile from the point of view of single actors. For example, regarding waste management, this might be true for a single household management waste unit on the municipal or regional level. In an effort to narrow this gap the Federal Ministry of Agriculture Forestry, Environment and Water Management has developed a 
management tool (see Box 4), which is offered free of charge to municipalities and public waste management units. This instrument is already applied in one state (Styria). It is important to quantify the impact of this tool on environmental efficiency in order to increase compliance with this and other measures, which rely on voluntary co-operation.

\section{Box 4. An example for improving cost awareness}

\section{The Austrian Waste Management Tool}

The development of this instrument has been commissioned by the Federal Ministry of Agriculture, Forestry, Environment and Water Management and was elaborated from 1996 to 2004 as a decision support tool for the judgment of different measures in the field of management of municipal waste in Austria. Based on various processes and mass fluxes, the computer model describes environmental effects as well as business costs of specific waste collection and treatment options. Using the scenario method, different measures can be compared concerning their current and future economic and ecologic effects.

Application of the tool can be expected to increase cost consciousness and to provide a basis for decisionmaking taking into account a more complete information set. In particular, the tool allows to calculate:

- costs of legal measures

- $\quad$ costs versus ecologic effects of different measures

- $\quad$ the cost-minimising policy mix to reach ecologic goals

- $\quad$ the most cost effective implementation of legal measures

The waste management tool was developed and designed to be used on the basis of standard software. With the input of expert knowledge, the computer model can be adapted for other regions.

This computer model will also be used for the assessment of policy measures.

Source: The Federal Ministry of Agriculture, Forestry, Environment and Water Management (III/6).

\section{Towards higher accountability of the budgeting process}

51. Linking fiscal consolidation to public sector reform requires a rigorous approach to evaluating and prioritising public sector spending projects. Both budgetary autonomy of the different layers of government in the federation and the existence of an elaborate system of fiscal linkages between them require efficient budgetary processes and inter-governmental co-ordination. This necessity is reinforced by the provisions of the Maastricht treaty, relating to the general government, to meet the $3 \%$ deficit limit and balance the budget in the medium term. In 2001 the federal government, the states and the municipalities agreed on the first Domestic Stability Pact designed to support implementation of Austria's fiscal consolidation targets (Box 5). While this marked progress in institutional reform, recent experience indicates that meeting the targets of the Domestic Stability Pact have contributed to budgeting practices which blur spending commitments falling due in the future, highlighting the need for reforms of the budgeting framework. 


\section{Box 5. Domestic Stability Pact}

In the Domestic Stability Pact the federal government, the states and the municipalities agree on balance targets for the three levels of government as well as on sanctions in case of a party's non-compliance with the target. A new agreement was negotiated for the period 2005-08. The federal government is subject to a deficit ceiling of $2.4 \%$ in 2005 , declining to $1.2 \%$ in 2008. The states have to reach a surplus of $0.6 \%$ of GDP in 2005 and 2006 , rising to $0.7 \%$ of GDP in 2007 and 2008. Specific surplus targets are attributed to each of the 9 states, largely according to population, with less affluent states facing a somewhat smaller surplus requirement. Municipalities have to keep a balanced budget throughout the 4-year period. The balanced budget requirement does not however apply to each individual municipality. Instead, the target is applied to the municipalities within each state on aggregate. Any sanctions for exceeding deficit requirements would also be born by all municipalities in the state. ${ }^{1}$

The budget balance requirements are determined with respect to the actual balance, rather than with respect to a measure of structural balance, although the stability pact provides some flexibility, as the federal government, state governments and municipalities are allowed temporary underruns of $0.25 \%, 0.15 \%$ and $0.1 \%$ of GDP, respectively, on aggregate. Such underruns have to be made up in other years such that the target is reached on average. However, such underruns are only permitted in 2007 and 2008, not in 2005 and 2006. The sanction mechanism also provides an escape clause for cyclical deficits. Except to compensate temporary balance underruns, surpluses are not transferable to future years, but can be transferred to other jurisdictions through written declaration, in which case they do not count towards the average deficit requirement of the transferring jurisdiction.

Classification criteria to calculate budget balances for the purposes of the Domestic Stability Pact are different from those which apply to the national accounts in 2005 and 2006. In particular, some sales of government real estate, which since 2001 have not counted towards deficit reduction in the national accounts, will continue to improve budget balances for the purposes of the Austrian Domestic Stability Pact in these two years.

Governments that fail to reach the target on average over the period of the stability pact would have to pay a fixed and variable fine totalling $8 \%$ of the absolute amount of the targeted balance and $15 \%$ of the shortfall, respectively, up to a ceiling (thus, the municipalities are not liable to a fixed fine, as they are required to generate neither a surplus nor a deficit). Sanctions arising from non-compliance with the $3 \%$ deficit ceiling of the Maastricht treaty are also distributed across domestic governments. In each case, however, application of sanctions depends on the unanimous decision of a commission involving the federal government on the one hand, and the states or the municipalities on the other hand. Also, the agreement specifies circumstances under which targeted government balances need to be renegotiated - such as a significant economic slow-down - and no sanctions apply. There is no obligation to publish budget balances according to the Domestic Stability Pact. Similarly, transfers of surpluses between governments are not published.

In order to adhere to the rules of the Domestic Stability Pact, the states, in particular, took measures which reduced their measured deficits which do not improve the level of future spending obligations of the states. Net lending of states to government-funded hospitals amounts to about $0.3 \%$ of GDP per year. In particular, transfers of state governments to public-sector financed hospitals were replaced by loans to hospitals. Moreover, the obligations of the stability pact induced the states to provide housing subsidies as loans at interest rates below market values, rather than direct grants.

1. For more details on the Austrian Domestic Stability Pact, see Diabalek et al. (2005).

\section{Improving the budgeting framework at all levels of government}

52. On several counts there is significant scope to improve the budgeting framework at the different levels of government as a fundamental tool for fiscal decision making.

53. First, since 1996 the federal government has presented "double budgets" to Parliament, each covering two years. Parliament decides over appropriations for the first of the two consecutive years, while the second year is added so as to improve the continuity of the budgetary process. While this marks progress over single-year budgeting there is no medium-term budget framework available that accounts for 
envisaged future developments of spending and revenue items. Within the present setting, a number of future spending commitments remain unrecorded such as the states' future pension obligations for public sector employees that can be expected to weigh heavily in the states' future spending. This substantially complicates policy planning and evaluation. Moreover, future inter-governmental negotiations on revenue sharing and deficit targets may be confronted with demands by the states to fund obligations for which insufficient provisions were made in the past. This risks putting fiscal sustainability under stress and could lead to agreements between the parties involved that jeopardise the quality of general government spending.

54. Second, the budgeting process would need to be better geared toward programme orientation. As has been highlighted in recent Economic Surveys of Austria, progress has been made in introducing instruments that enhance performance orientation of the federal administration. In particular, for some federal administrative units the fungibility of funds was raised, creating incentives to attain budgetary outcomes that are better than targeted. ${ }^{48}$ However, the budgeting system is still lacking focus on policy outcomes. The federal budget provides a very detailed description of appropriations that are input based, and this is true as well for the budgets of the states. Correspondingly, legislation focuses on parliamentary control of inputs as opposed to budgetary appropriations on a programme or activity basis. In contrast, since the 1980s, many OECD countries, such as the United Kingdom, northern European countries, New Zealand and the United States, have relaxed input controls and reoriented budget systems to focus on results. In exchange for more flexibility in budget management, in this approach decentralised managers now have greater responsibility for achieving results from a relatively small number of government programmes. Accordingly, budget laws have been changed to simplify the structures of budget appropriations approved by parliament. For example, in France full introduction of a programme-oriented budget is scheduled for 2006, with only about 150 programmes ("budget lines") to be approved by Parliament.

55. Third, Austrian legislation requires that budgeting is based on cash rather than accruals. By contrast, accrual accounting is supplementary to an outcome-based budgeting approach in that it makes the full cost of government activities more transparent, thereby improving decision making by using this enhanced information.

56. Fourth, while major accounting principles are valid for all layers of government, some accounting rules are not completely harmonised between the different governments. In particular, transactions between the states and the municipalities are often opaque. Transactions may be recorded inconsistently by paying and receiving jurisdictions. Similarly, identification of inter-governmental transfers between the states and the municipalities is often not possible. ${ }^{49}$

57. Fifth, basing spending and revenue decisions on ex ante and ex post evaluations of benefits and costs requires that the policy relevant information is available at all levels of government. ${ }^{50}$ An important benefit of decentralised provision of government services is that it creates the potential to benchmark performance of states and municipalities with the performance of their peers, introducing a degree of competition among states and municipalities that encourages innovative policies and the adoption of best practice. Indeed, transparency and benchmarking has helped increase efficiency gains from devolved provision of government services, for example, in Denmark and Norway. In Austria, transparency of the federal administration has increased in recent years as ministries present themselves with their core and non-core services in annual performance reports, which also contain summary indicators on service provisions. However, systematic evaluation of the costs and benefits of policy programmes is widely lacking and important information is often not available at the different levels of government. In particular, resources utilised for the production of municipal services, notably employment, appears to be insufficiently accounted for. On the level of the general government, data on employment are often not consistent with corresponding data on personnel expenditure. Transparency is also lacking in several other 
areas, such as the administration of social assistance, state hospitals and the civil service pension liabilities of the states. ${ }^{51}$ In some cases, inadequate information on key features of budgetary spin-offs have also prevented appropriate evaluations of their economic performance. Indeed, as considered in the 2001 Economic Survey on Austria, there is evidence that spin-offs of entities from government budgets did not always yield the desired results.

58. Sixth, extra-budgetary funds segregate the information base for policy makers, widening the gap between a comprehensive budgeting approach for the general government as it underlies the Maastricht treaty and administrative accounting practices. For example, a surplus is created within the fund if the fund's earmarked revenues exceed the fund's spending, whereas the "regular" administrative budget of the government remains unaffected. Similarly, an increase in earmarked spending financed out of the fund's revenues would not be reflected in increases in the government deficit in administrative terms. This might add to the bias in favour of higher spending (see above).

59. Hence, facilitating the setting of spending priorities by policy makers suggests fundamental revisions to the budgeting framework at all levels of government. A medium-term budget framework should be introduced at all levels of government in the same systematic way as in the annual budgets and allowing accounting of envisaged budgetary appropriations to be detailed enough to make the causes for spending and revenue pressures transparent. Long-term fiscal pressures should also be made transparent. Moreover, the input-oriented budget items at the levels of the federal government and the states and municipalities should be adapted so as to introduce output-oriented budgeting. This would entail basing budgetary appropriations around programmes, within a simplified budgetary framework, associated with the requirement to supply an analysis of the costs and the benefits of such programmes to parliaments. Within this setting, ministries would be held responsible for the programme management. Moreover, the information base for cost and benefit analysis of spending and revenue programmes needs to be improved, and the accounting framework should be fully harmonised across government levels.

\section{Re-enforcing inter-governmental co-operation}

60. The Domestic Stability Pact would be re-enforced by adoption of a medium-term consolidation rule at each level of government. Experience within the OECD indicates that in cyclical downswings a rule requiring budgets to be balanced might not be obeyed, which in turn can impair the credibility of the consolidation strategy. More appropriate would be a rule - as adopted in Switzerland by some Cantons and legislated for the federation - requiring the budgets to be balanced over the cycle.

61. The more often revenue allocations are negotiated between the different administrations the higher the risks are that agreed-upon deficit caps are not considered effectively binding. Hence, relatively frequent re-negotiation of the Fiscal Equalisation Law, which is currently renewed every 4 years (see Box 2), is likely to weaken inter-temporal budget constraints to sub-national governments' spending decisions, easing incentives for budgetary consolidation. Transaction costs also rise with the frequency of negotiations. Hence, revenue allocations to the different levels of government should be fixed for a longer period than four years. This would not need to imply a lower degree of flexibility in financial endowments if the revenue raising power of the sub-central governments were increased.

62. In the discussions on constitutional reform in Austria, proposals have emerged to give the states powers to block federal fiscal legislation in the Bundesrat, the second chamber of parliament, on matters that affect them financially. Such powers for the states may however make it difficult to find the necessary political consensus for reforms, as state governments might condition their approval to federal fiscal legislation on concessions in federal legislation that does not require the approval of the Bundesrat. Instead, constitutional reform should disentangle decision-making powers of the different layers of government. In Germany, whose federal structure resembles the Austrian one in several respects, attempts 
are being made to scale down the blocking power of the states in the second chamber of parliament. Indeed, these blocking powers have considerably slowed the reform process and reduced its transparency. ${ }^{52}$

63. Instead, there is scope to improve the system of inter-governmental co-ordination in another important respect. A consultation mechanism was already introduced in 1998 in order to deal with cost spillovers of legislation originating from the federal or the state level on other levels of government, compelling the legislating level of government to reimburse other levels of governments for such cost spillovers. Any local, state or the federal government can invoke the mechanism if costs it has to bear rise as a result of legislative action by another level of government. The consultation mechanism has improved incentives to take administrative costs into account more fully when introducing new legislation, and has already been used. However, the mechanism is asymmetric in that it does not generally allow spillovers of cost saving legislation to be internalised. In particular, if a government introduces legislation that reduces administrative costs to other levels of government it cannot, in general, demand reimbursement from the levels of governments which benefit from the cost reduction. ${ }^{53}$ Thus, while the consultation mechanism creates incentives to avoid cost-generating legislation, it does not fully exploit incentives for cost-saving legislation. In addition, while the governments involved in negotiations on cost reimbursement can agree on lump-sum payments to offset cost spillovers, court settlements, which comes about if parties fail to agree, result in reimbursements of ex post costs. However, cost reimbursements based on historic costs may reduce incentives to minimise costs in the government receiving the compensation. The consultation mechanism should therefore be amended in a way that takes into consideration both positive and negative cost externalities, allowing governments to invoke the mechanism when they pass legislation generating cost savings for other governments. Compensating payments should be made on an ex-ante basis, rather than on the basis of ex-post cost. 


\section{Notes}

1. This paper was originally produced for the OECD Economic Survey of Austria, published in May 2005 under the responsibility of the Economic and Development Review Committee. The authors wish to thank Jørgen Elmeskov, Isabelle Joumard, Douglas Sutherland and other members of the department for useful comments on previous drafts of this paper. The Austrian Ministry of Finance, the WIFO Austrian Institute for Economic Research and the IHS Institute for Advanced Studies provided valuable data and insights. The authors also thank Margaret Morgan, Susan Gascard and Sheila McNally for technical assistance.

2. Thöni (2002).

3. OECD (1997).

4. Figures as of end-2002 from Staatsschuldenausschuss (2004).

5. Convergence of GDP per capita among districts and states was found to be on average $2 \%$ per year by Hofer-Wörgötter (1997), but seems to have accelerated more recently.

6. See Schratzenstaller (2004).

7. The volume of discretionary grants however often deviates from the $13 \%$ proportion prescribed in the FAG.

8. The weights are those of the weighed population key noted above. Different real estate tax rates are used in the two different equalisation transfers, outlined below.

9. See Matzinger (2002).

10. Lehner (2003), data from 2000. The share is likely to have diminished further after 2000.

11. Excluding Vienna, which is both a municipality and a state.

12. Bröthaler et al. (2002).

13. Real estate values for tax purposes have been uniformly increased by $35 \%$ following the last valuation exercise in 1973.

14. Joumard and Kongsrud (2003).

15. Schneider (2002).

16. See Joumard and Kongsrud (2004). Limits on sub-national income tax-setting powers are also imposed in Spain and Mexico, while Denmark and Sweden experienced upward drifting personal income tax rates set by sub-national governments.

17. For the municipalities this has been estimated by Bröthaler et al. (2002).

18. Matzinger (2002).

19. Schönbäck et al. (2004). 
20. Beginning in 2001 states were also allowed to make free use of repayments received from subsidised loans granted under the scheme.

21. Matzinger (2002).

22. See Schneider (2002).

23. WKÖ (2004).

24. Lehner (2003).

25. Lehner (2003).

26. Joumard and Kongsrud (2003).

27. Lehner (2003).

28. OECD (2005).

29. Lehner (2003).

30. Lehner (2003).

31. Analysis of flood events 2002 - FloodRisk, interdisciplinary project carried out at the Ministry of Agriculture, Forestry, Environment and Water Management with more than 150 participating experts. The project also benefited from co-operation with Swiss government institutions.

32. See Bock-Schappelwein (2004).

33. Statistical information on the extent to which the states re-claims benefits is incomplete. However, the ratio between SH spending and revenues on account of the SH system varies substantially between states ranging from $110 \%$ to $3 \%$ in 2001 - which might reflect to some extent differences in regress policies. For example, the state of Vienna does not reclaim SH benefits. However, the variation in the revenues ratio might be overstated as reporting across states is uneven. Some states do not report full revenues to Statistics Austria, and in some cases revenue items are included which are not strictly associated with SH granted to households. See Bock-Schappelwein (2004).

34. Streissler (2004).

35. See e.g. Hofmarcher et al. (2004).

36. Rechnungshof (2002). In particular, state and municipality funding to cover deficits of hospitals are not recorded as health spending. In addition long-term care for the elderly which is recorded as health spending in other OECD countries is not recorded as health spending in Austria.

37. Streissler (2004). OeNB (2004). Reclassification of subsidies as loans has resulted in a reduction of general government spending and the general government's deficit, as measured in the national accounts, by about $0.3 \%$ of GDP.

38. Including funding provided by hospital owners, which in most cases are the States and the municipalities. Patients out-of-pocket spending and private health insurance contribute 5\%, social assistance $1 \%$ of revenues.

39. The Landesgesundheitsfonds replaced the Landesfonds in 2004. See Box 3.3 for details. 
40. The funds of the federal government and social security are distributed across hospitals according to a DRG system.

41. The states also played a predominant role in the Landesfonds which were in charge of hospital funding before introduction of the LGFs.

42. Hofmarcher and Riedel (2001).

43. See e.g. Streissler (2004).

44. Austrian hospital discharge statistics include same-day discharges since 1996, which is not the case in most OECD countries, making Austrian hospital discharges appear larger relative to other countries. However, those OECD countries which also include same-day separations in discharage statistics - Hungary, Luxembourg, New Zealand and the Unites States - have substantially lower discharges than Austria. See OECD (2003b).

45. Docteur and Oxley (2003).

46. Hofmarcher et al. (2005), Hofmarcher et al. (2002).

47. See the 2003 OECD Environmental Performance Review for Austria.

48. See OECD (2003).

49. Österreich-Konvent (2004).

50. See OECD (2001).

51. Staatsschuldenausschuss (2003).

52. OECD (2004b).

53. Measures that reduce administrative costs at other levels of government are only taken into account if reimbursement of a cost-increasing measure is being negotiated, in which case the former are deducted from the latter. See Matzinger (2002). 


\section{BIBLIOGRAPHY}

Arbeiterkammer (2004), Gesundheitsagenturen - Verbessserung des Schnittstellenmanagements im Gesundheitswesen? Gesundheit \& Soziales info, No. 3, April.

Aufgabenkommission (2001), Bericht der Aufgabenkommission, mimeo.

Bock-Schappelwein, J. (2004), Arbeitslosigkeit und offene Sozialhilfe in Österreich - Eine quantitative Analyse, Österreichisches Institut für Wirtschaftsforschung, Vienna.

Bröthaler, J., L. Sieber, W. Schönbäck, A. Maimer and H. Bauer (2002), Aufgabneorientierte Gemeindefinanzierung in Österreich. Vienna, New York: Springer.

Diebalek, L., W. Koehler-Toeglhofer, D. Prammer (2005), “The Austrian Stability Pact 2001-2004 Design, Objectives and Effectiveness", forthcoming in: Wirtschaftspolitische Blätter 2/2005.

Docteur, E. and H. Oxley (2003), "Health-care Systems: Lessons from the Reform Experience", OECD Economics Department Working Papers, No. 374, OECD, Paris.

Grossmann, B. and E. Hauth (2004), Entwicklung der öffentlichen Beschäftigung in Österreich. Projektstudie im Auftrag des Staatsschuldenausschusses, Vienna, mimeo http://www.staatsschuldenausschuss.at/html/download/Studie_Beschaeftigung.pdf

Hofmarcher, M. M., I. Paterson and M. Riedel (2002), "Measuring Hospital Efficiency in Austria- A DEA Approach", Health Care Management Science, No. 5, pp. 7-14.

Hofmarcher, M. M., C. Lietz and A. Schnabl (2005), "Inefficiency in Austrian Inpatient Care: An Attempt to Identify Ailing Providers", Department of Economics and Finance, HIS Institute of Advances Studies, Vienna.

Hofmarcher, M. M. and M. Riedel (2001), Gesundheitsausgaben in der EU: Ohne Privat kein Staat. Schwerpunktthema: Das Österreichische Krankenanstaltenwesen-eines oder neun Systeme? Health System Watch, Spring.

Hofmarcher, M. M., M. Riedel and G. Röhrling (2004), "Health Expenditure in the EU: Convergence by Enlargement? Focus: Health Remains Precious to Us - So What?" Health System Watch, I/Spring, htpp://www.ihs.ac.at/departments/fin/HealthEcon/watch/hsw04_le.pdf(20/11/04).

Hofmarcher, M. M. and G. Röhrling (2003), Gesundheitsausgaben in der EU: DieVergleichbarkeit kränkelt. Vorausschätzung der Gesundheitsausgaben in Österreich, Health System Watch, Vol. I, Spring.

Joumard, I. and P. Kongsrud (2003), "Fiscal Relations Across Government Levels", OECD Economics Department Working Papers, No. 375, OECD, Paris. 
Lehner, G. (2003), Aufgabenorienterter Finanzausgleich, Österreichisches Institut für Wirtschaftsforschung, Vienna.

Matzinger, A. (2002), Finanzausgleich, in: G. Steger (ed.), Öffentliche Haushalte in Österreich, Verlag Österreich, Vienna, pp. 51-95.

McLure, C. E. (2000), Tax Assignment and Sub-national Fiscal Autonomy, International Bureau of Fiscal Documentation Bulletin, December.

Oates, W. E. (1999), “An Essay on Fiscal Federalism”, Journal of Economic Literature, Vol. 37.

OECD (1997), Managing Across Levels of Government, Directorate: GOV, OECD, Paris.

OECD (2001), OECD Economic Surveys: Austria, Vol. 2001/3, OECD, Paris.

OECD (2003a), OECD Economic Surveys: Austria, Vol. 2003/16, OECD, Paris.

OECD (2003b), Health at a Glance, OECD, Paris.

OECD (2004a), OECD Economic Surveys: Euro Area, Vol. 2004/5, OECD, Paris.

OECD (2004b), OECD Economic Surveys: Germany, Vol. 2004/12, OECD, Paris.

OECD (2005), OECD Economic Surveys: Spain, Vol. 2005/6, OECD, Paris.

Österreich-Konvent (2004), Anlage 10 - Die Gemeinden im Netz der intergovernmentalen Transferbeziehungen.

Rechnungshof (2002), Tätigkeitsbericht des Rechnungshofes, Vorarlberg, Verwaltungsjahr 2002

Schneider, M. (2002), "Local Fiscal Equalisation Based on Fiscal Capacity: The Case of Austria", Fiscal Studies, Vol. 23, No. 1.

Schönbäck, W., J. Bauer and J. Bröthaler (2004), Die Gemeinden im Netz der intragovernmentalen Transferbeziehungen, Endbericht.

Schratzenstaller, M. (2004), Bundesvoranschlag 2005: Hohes Defizit durch Steuerreform und steigende Transferausgaben, Wifo Monatsberichte 11/2004.

Schratzenstaller, M. (2005), Neuer Finanzausgleich und Stabilitätspakt - keine grundlegenden Änderungen. Wifo Monatsberichte 1/2005.

Staatsschuldenausschuss (2004) Bericht über die öffentlichen Finanzen 2003, Vienna.

Streissler, A. (2004), Das österreichische Gesundheitswesen. Eine ökonomische Analyse aus interessenpolitscher Sicht. Materialien zu Wirtschaft und Gesellschaft, No. 89, August.

Thöni, E. (2002), Der Stellenwert des Finanzausgleichs: Reformdruck, Problemdarstellung und internationale Perspektiven, in: B. Rossman (ed.) Finanzausgleich- Herausforderungen und Reformperspektiven, pp. 9-21. Wirtschaftswissenschaftliche Tagungen der AK Wien. Vienna.

WKÖ (2004), Gründungsoffensive "Gesundheitsberufe”, mimeo. 


\section{WORKING PAPERS}

The full series of Economics Department Working Papers can be consulted at www.oecd.org/eco/Working_Papers/

473. Product market competition and economic performance in France

Concurrence sur les marches de produits et performance économique en France

(January 2006) Jens Høj and Michael Wise

472. Product market reforms and employment in OECD countries

(December 2005) Giuseppe Nicoletti and Stefano Scarpetta

471. Fast-falling barriers and growing concentration: the emergence of a private economy in China (December 2005) Sean Dougherty and Richard Herd

470. Sustaining high growth through innovation: reforming the R\&D and education systems in Korea (December 2005) Yongchun Baek and Randall Jones

469. The labour market in Korea: enhancing flexibility and raising participation (December 2005) Randall Jones

468. Getting the most out of public-sector decentralization in Korear (December 2005) Randall Jones and Tadashi Yokoyama

467. Coping with the inevitable adjustment in the US current account (December 2005) Peter Jarrett

466. Is there a case for sophisticated balanced-budget rules? (December 2005) Antonio Fatás

465. Fiscal rules for sub-central governments design and impact (December 2005) Douglas Sutherland, Robert Price and Isabelle Joumard

464. Assessing the robustness of demographic projections in OECD countries (December 2005) Frédéric Gonand

463. The Benefits of Liberalising Product Markets and Reducing Barriers to International Trade and Investment in the OECD

(December 2005)

462. Fiscal relations across levels of government in the United States (November 2005) Thomas Laubach

461. Assessing the value of indicators of underlying inflation for monetary policy (November 2005) Pietro Catte and Torsten Sløk.

460. Regulation and economic performance: product market reforms and productivity in the OECD (November 2005) Giuseppe Nicoletti and Stefano Scarpetta.

459. Innovation in the Business Sector

(November 2005) Florence Jaumotte and Nigel Pain

458. From Innovation Development to Implementation: Evidence from the Community Innovation Survey (November 2005) Florence Jaumotte and Nigel Pain 


\section{ECO/WKP(2006)2}

457. From Ideas to Development: the Determination of $R \& D$ and Patenting (November 2005) Florence Jaumotte and Nigel Pain

456. An Overview of Public Policies to Support Innovation (November 2005) Florence Jaumotte and Nigel Pain

455. Strengthening Regulation in Chile: The Case of Network Industries (November 2005) Alexander Galetovic and Luiz de Mello

454. Fostering Innovation in Chile (November 2005) José-Miguel Benavente, Luiz de Mello and Nanno Mulder

453. Getting the most out of public sector decentralisation in Mexico (October 2005) Isabelle Joumard

452. Raising Greece's Potential Output Growth (October 2005) Vassiliki Koutsogeorgopoulou and Helmut Ziegelschmidt

451. Product Market Competition and Economic Performance in Australia (October 2005) Helmut Ziegelschmidt, Vassiliki Koutsogeorgopoulou, Simen Bjornerud and Michael Wise

450. House Prices and Inflation in the Euro Area (October 2005) Boris Cournède

449. The EU's Single Market: At Your Service? (October 2005) Line Vogt

448. Slovakia's introduction of a flat tax as part of wider economic reforms (October 2005) Anne-Marie Brook and Willi Leibfritz

447. The Education Challenge in Mexico: Delivering Good Quality Education to All (October 2005) Stéphanie Guichard

446. In Search of Efficiency: Improving Health Care in Hungary (October 2005) Alessandro Goglio

445. Hungarian Innovation Policy: What's the Best Way Forward? (October 2005) Philip Hemmings

444. The Challenges of EMU Accession Faced by Catch-Up Countries: A Slovak Republic Case Study (September 2005) Anne-Marie Brook

443. Getting better value for money from Sweden's healthcare system (September 2005) David Rae

442. How to reduce sickness absences in Sweden: lessons from international experience (September 2005) David Rae

441. The Labour Market Impact of Rapid Ageing of Government Employees: Some Illustrative Scenarios (September 2005) Jens Høj and Sylvie Toly

440. The New OECD International Trade Model (August 2005) Nigel Pain, Annabelle Mourougane, Franck Sédillot and Laurence Le Fouler

439. The French Tax system: Main characteristics, recent developments and some considerations for reform (July 2005) Willi Leibfritz and Paul O'Brien 